\title{
Delphine Parrott, a pioneer of T cell biology
}

Delphine M. V. Parrott (1928-2016) was one of the foremost woman scientists of her generation, being a pioneer of $\mathrm{T}$ cell immunology and mucosal immunology, as well as making seminal findings on lymphoid anatomy and lymphocyte recirculation.

Delphine was born near London, graduating in Physiology at Bedford College and completing her $\mathrm{PhD}$ at King's College London in 1952. She began her scientific career as an endocrinologist, working on reproductive physiology and then on olfactory sensation, based in London and Edinburgh, before moving to the Imperial Cancer Research Fund in London to study the thymus. Here, she made use of the surgical skills she had acquired working on endocrine organs to study the effects of thymectomy on the immune system. This led to the seminal finding that removal of the thymus from neonatal mice caused a wasting disease, lymphopenia and immunosuppression. This was a highly competitive field at the time and, although Delphine's study was eventually published in Nature in 1962 , delays in the process meant that this was some time after Jacques Miller's paper in the Lancet describing the immunological role of the thymus. As a result, Delphine never received the full recognition she deserved for the discovery, something she would say in later life that reflected the prejudice against woman scientists at the time. Subsequent studies with Maria de Sousa revealed the presence of a 'thymus-dependent area' in secondary lymphoid organs where lymphocytes proliferated after immunization with antigens that induced cell-mediated immunity. This also led to the proposal that resting, thymus-derived lymphocytes recirculated continuously in and out of lymphoid organs. More than 50 years later, these early studies still constitute some of the most fundamental pillars of cellular immunology.
Lymphocyte recirculation and anatomical niches within the immune system were to remain Delphine's main focus for the rest of her career. After moving to the University of Glasgow in 1967, she and her trainees, who included Maria de Sousa, Marlene Rose, Antonio de Freitas, Anne Ferguson, David Bruce and Cliff Ottaway, defined the ground rules for the tissue-specific migration of T cells around the body. Together, they showed that activated $\mathrm{T}$ lymphoblasts 'remembered' their tissue of origin, for instance, migrating back to the intestine only if primed in intestine-draining lymph nodes in a process determined by nonantigen-specific factors. These insights remain fundamental to our understanding of lymphocyte trafficking, vaccine development and mucosal immunology. They led to Delphine developing a particular interest in intestinal immunology, which in the 1970s was a neglected area of research. She became a pioneer of this field, being one of the few people to focus on T cells and generating some of the first insights into the intraepithelial lymphocytes (IELs) found in the intestine. In particular, Delphine helped show that IELs were antigen dependent, capable of potent cytotoxic activity and linked with coeliac disease.

In 1973, Delphine was appointed to a personal chair in Immunology, making her the first ever woman Professor at the University of Glasgow and, it has to be said, in the face of not inconsiderable local resentment. In 1980, she became Head of Department of Bacteriology and Immunology, before retiring in 1990. During her time in Glasgow, she was a driving force in establishing the Bachelor's degree in Immunology, which in 1975 was one of the first of its kind in the UK. In this, she again faced considerable opposition from other local biologists who did not consider Immunology to be a subject

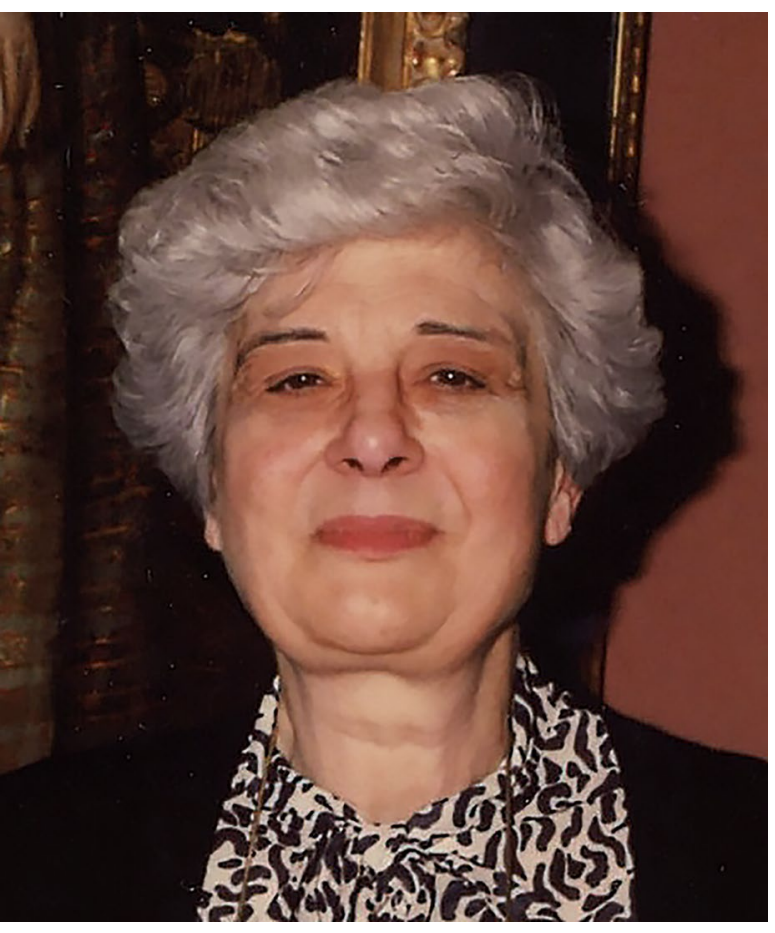

Credit: Image courtesy of University of Glasgow Archives \& Special Collections, GB248 Accn4205/1/3.

worthy of its own degree status; UK immunology owes much to her
Delphine never received the full recognition she deserved for the discovery, something she would say in later life that reflected the prejudice against woman scientists at the time

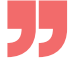
vision and determination in ensuring the success of her initiative.

In person, Delphine's formidable intellect and wisdom concealed a wicked sense of humour and a great ability to see through the least sign of artifice. Unflinching integrity and a rigorous approach to science, allied to a lack of ego, made her the ideal role model and mentor. It's probably no coincidence that many of her most successful trainees were, like her, women finding their way through the often hostile world of late 20th century academia. \section{gow, Scotland, UK e-mail: Allan.Mowat@gla.ac.uk \\ The author declares no competing interests.}

ORIGINAL ARTICLES Parrott, D. M. V. \& East, J. Role of the thymus in neonatal life. Nature 195, 347-348 (1962) | Parrott, D. M. V. \& de Sousa, M. A. B. Changes in the thymus-dependent areas of lymph nodes after immunological stimulation. Nature 212, 1316-1317 (1966) | Parrott, D. M. V., de Sousa, M. A. B. \& East, J. Thymus-dependent areas in the lymphoid organs of neonatally thymectomized mice.J. Exp. Med.123, 191-204 (1966)|Rose, M. L., Parrott, D. M. V. \& Bruce, R. G. Migration of lymphoblasts to the small intestine. II. Divergent migration of mesenteric and peripheral immunoblasts to sites of inflammation in the mouse. Cell. Immunol. 27, 36-46 (1976)| Davies, M. D. J. \& Parrott, D. M. V. Cytotoxic T cells in small intestine epithelial, lamina propria and lung lymphocytes. Immunology 44, 367-371 (1981) 